No. 4001 July 6, 1946

slightly smaller than the first, two smaller dishes, embossed with figures, several ornamented bowls, a pair of standing cups, a large fluted bowl with a pentacle as ornament at its centre, a number of detached handles, spoons, small cups and ladles, and a convex ornamented cover with the figure of a child as handle. The large circular dish is a remarkable piece on rsthetic grounds, apart from its size and weight. It is a characteristic example of RomanoBritish style of the later period of the Roman occupation, crowded with exuberant figures executed with great technical skill (see Illus. London News, June 29). There are many points of interest connected with this find which no doubt will give rise to much discussion in the future. It is possible to mention here only one-that of the dating. It has been suggested that the hoard may have been buried about the end of the third century of our era, that is, about A.D. 300 , but a later date by some fifty years seems possible. Apparently this find belongs to that class which consists of household goods of villas buried when in danger from raiders. But according to the evidence of coins from such hoards, this practice did not begin until near the middle of the century and came to an end when in A.D. 367 Romano-British villa life in East Anglia suffered its final blow at the handg of barbarian sea-raiders.

\section{Rayon Technology at Manchester}

Is accordance with their declared policy of providing financial assistance for the development of technical education Nubjects of importance to the British raygn if (unstry, Messrs. Courtaulds, Ltd., last week anno Agdd a gift of $£ 60,000$ to the Manchester Collegedf rechnology, which is also the Faculty of If 4 phogy in the University of Manchester. The n.My will for the most part be used for completely re-eqtipping the two Departments of Textile Industries and Textile Chemistry with up-to-date machinery and apparatus for training and research in rayon technology. The gift is particularly opportune because building is about to be resumed on the considerable extensions to the College which were started before the War and in which space had already been earmarked for rayon development, especially in reference to research. These plans can now be brought to fruition much more completely and more quickly than would otherwise have been possible.

The past decade has witnessed a notable increase in the number and variety of man-made fibres available to the textile industries. Of equally great importance, however, are the great strides that have been made in the study of their behaviour and properties, and in the growing appreciation of their independent significance in the textile economy as a whole. This has led, on one hand to the opening up of new fields of application, and on the other to a complete re-consideration of the orthodox sequence of industrial operations by which these materials in their different forms are commonly spun, woven, dyed and finished. The fundamental principles of fibre treatment are for the most part applicable to all textile materials, whatever their origin; but in the application of these principles, so far as the rayons are concerned, there are now in prospect more radical departures from orthodox practice than have been made hitherto. As a result of Messrs. Courtauld's gift, the Manchester College of Technology will be able not only to demonstrate the latest types of machinery and process but also play a much larger part, by experiment and research, in contributing to their further development.

\section{Education in the Royal Air Force}

THE Air Gouncil has now approved the formation of an Edacation Branch of the Royal Air Force in place of the civilian Educational Service that has existed hitherto. Education officers will now become part of the Royal Air Force itself, instead of being members of a civilian auxiliary service. The R.A.F. Education Branch, which will consist of commissioned officers only, will be constituted on the same broad lines as other branches of the Royal Air Force. The Branch will be organised on a predominantly shortservice basis, provision being made for a percentage of short-service officers to be granted permanent commissions. Vacancies in the permanent cadre will normally be filled from the ranks of short-service officers, but officers with qualifications of outstanding value to the R.A.F. may exceptionally be appointed direct to permanent commissions. The intention is that officers should be appointed to short-service commissions, for a period of five years on the active list followed by four years on the reserve, and that they will enter at an average age of twenty-five in the rank of flying officer, normally after having had some civil teaching experience.

Service in the Education Branch of the Royal Air Force will be recognized by the Ministry of Education for determining the correct incremental position on the Burnham scales of salary of teachers who afterwards enter or return to civilian teaching employment. Further, the period of the short-service engagement of officers of the Education Branch who have been in contributory service under the Teachers (Superannuation) Acts will reckon as contributory service towards any ultimate award of pension under those Acts. It is hoped that it will be possible to make similar provision for short-service officers who were not in contributory service before entering the Branch. Candidates for appointment to the Branch must be in possession of a full degree of a university or an equivalent qualification obtained by examination, and the possession of first- or second-class honours will normally be a requirement for appointment to a permanent commission. A detailed announcement will be made as soon as possible with regard to the conditions of entry to and service in the new Branch, together with information regarding the conditions of assimilation of existing members of the R.A.F. Educational Service.

\section{International Academy of the History of Science}

THE activities of the International Academy of the History of Science were suspended during the War. Prof.Aldo Mieli, the permanent secretary, is not at present able to leave Buenos Aires, and it has not yet been possible to resume publication of Archeion, the fournal of the Academy. It has been decided, however, to hold a congress at Lausanne in the summer of 1947. All interested in the subject will be welcome, and the following provisional measures have been taken : J. A. Vollgraff (Roodbortsstraat 17, Leyden, Holland) is acting as secretary-treasurer, and Prof. P. Brunet (Hotel Nêvers, 12 Rue Colbert, Paris 2 lème) as archivist and librarian. Prof. Arnold Reymond, of Lausanne, was elected president at the last meeting and will preside at the next. A corrected list of the surviving members of the Academy is being compiled. Each individual member and each national group is urgently requested to send the necessary information either to Prof. Brunet or to M. Vollgraff. Suggestions for the replacement of 